\title{
PENENTUAN SIKLUS GLASIAL - INTERGLASIAL TERAKHIR PADA SEDIMEN DASAR LAUT KAWASAN LEPAS PANTAI PALABUHANRATU
}

\author{
Rina Zuraida1), Rainer A. Troa'), Marfasran Hendrizan ${ }^{3)}$, Eko Triarso2), Luli Gustiantini'1), Nazar Nurdin'), \\ Wahyu S. Hantoro ${ }^{3)} \&$ Shengfa Liu ${ }^{4)}$
}

1)Pusat Penelitian dan Pengembangan Geologi Kelautan, Badan Litbang ESDM, Kementerian ESDM

${ }^{2)}$ Pusat Penelitian dan Pengembangan Sumber Daya Laut dan Pesisir, Balitbang-KP, KKP

3) Pusat Penelitian Geoteknologi, LIPI

4)Marine Geology and Geophysics Division of the First Institute of Oceanography, State Oceanic Administration

Diterima tanggal: 20 Juni 2015; Diterima setelah perbaikan: 20 September 2015; Disetujui terbit tanggal 23 Oktober 2015

\begin{abstract}
ABSTRAK
Kawasan Lepas Pantai Palabuhanratu yang terletak di wilayah Jawa Barat bagian selatan dipengaruhi oleh dinamika laut Selat Sunda dan Samudera Hindia bagian timur. Kondisi ini terekam dalam sedimen dasar laut dan tersimpan sebagai informasi berbagai proses yang terjadi di perairan tersebut pada rentang waktu geologi tertentu. Penelitian ini menggunakan contoh inti sedimen dasar laut SO184-10043 (7 $7^{\circ} 18,57^{\prime}$ LS dan $105^{\circ} 3,45^{\prime}$ BT, kedalaman $2.166 \mathrm{~m}$, panjang $\left.360 \mathrm{~cm}\right)$ yang diambil pada saat cruise PABESIA dengan menggunakan kapal riset Sonne di Selat Sunda pada 2005. Metode penelitian yang digunakan adalah pentarikan umur (dating) radiokarbon $(14 \mathrm{C})$ dan analisis isotop oksigen $\left(\delta^{18} \mathrm{O}\right)$ pada foraminifera plankton Globigerinoides ruber. Hasil pentarikan umur isotop ${ }^{14} \mathrm{C}$ terhadap 16 cuplikan contoh menunjukkan bahwa contoh inti SO18410.043 merekam Siklus Glasial Terakhir hingga 35.000 tahun yang lalu. Hasil pengukuran $\delta^{18} \mathrm{O}$ memberikan nilai Deglasiasi yang lebih besar dari daerah sekelilingnya yang diduga akibat terhubungnya Laut Jawa yang memungkinkan mengalirnya air dari Laut Cina Selatan dengan salinitas dan suhu yang lebih rendah menuju Samudera Hindia melalui daerah penelitian. Rekonstruksi suhu permukaan laut dari data isotop $\delta^{18} \mathrm{O}$ memberikan nilai suhu deglasiasi yang jauh lebih tinggi yang diduga akibat faktor lokal yang mempengaruhi nilai salinitas di daerah penelitian.
\end{abstract}

Kata kunci: sedimen dasar laut, pentarikhan umur radiokarbon, $\delta^{18} \mathrm{O}$, Selat Sunda, Siklus Glasial Interglasial Terakhir, Deglasiasi

\begin{abstract}
Palabuhanratu waters in the southern part of West Java are affected by sea waters dynamics of Sunda Strait and Eastern Indian Ocean. These waters dynamic was recorded in marine sediments and stored as information of various processes occurring in the area in particular geological timescales. This study used marine sediment of core SO184-10043 (7 $7^{\circ} 18,57^{\prime}$ $S$ and $105^{\circ} 3,45^{\prime}$ E, $2166 \mathrm{~m}$ water depth, $360 \mathrm{~cm}$ long) acquired during PABESIA cruise onboard RV Sonne in 2005. The methods applied in this study were radiocarbon $\left({ }^{14} \mathrm{C}\right)$ dating and oxygene isotope $\left({ }^{18} \mathrm{O}\right)$ analysis on planktonic foraminifer Globigerinoides ruber. The result of radiocarbon dating on 16 subsamples shows that the core covered the Last Glacial Cycle up to 35,000 years ago. Oxygene isotope record indicates higher isotope values compared to surrounding waters that might be caused by connectivity of Java Sea which allows low salinity and cooler seawater of South China Sea flowing to the Indian Ocean through the study area. Reconstruction of sea surface temperatures from $\delta^{18} \mathrm{O}$ exhibits warmer Deglaciation temperature that might be related to local factors impacting salinity in Palabuhanratu waters.
\end{abstract}

\section{Keywords: seafloor sediment, radiocarbon dating, $\delta^{18} \mathrm{O}$, Sunda Strait, Last Glacial - Interglacial Cycle, Deglaciation}

\section{PENDAHULUAN}

Kawasan perairan Selat Sunda dan lepas pantai Palabuhanratu merupakan perairan yang berperan penting dalam oseanografi perairan Indonesia karena menghubungkan Laut Cina Selatan dengan Samudera Hindia. Saat permukaan laut surut pada Zaman Es Terakhir (Last Glacial Maximum atau LGM), Paparan Sunda yang tersingkap ke permukaan akan menghambat aliran air laut dari Laut Cina Selatan ke Samudera Hindia melalui Selat Sunda (Xu et al., 2010) sehingga mengurangi pasokan air laut bersalinitas rendah ke Samudera Hindia. Terhubungnya Laut Cina Selatan dengan Laut Jawa pada saat muka laut mencapai ketinggian antara 30 dan $40 \mathrm{~m}$ di bawah muka laut sekarang pada 9.000 tahun yang lalu (Xu et al., 2008) menyebabkan mengalirnya massa air yang relatif lebih tawar dari Laut Jawa ke Samudera Hindia. Intrusi massa air dari Laut Jawa ini diperkirakan akan menyebabkan terjadinya pengadukan massa air di Selat Sunda dan menghasilkan lapisan homogen yang tipis dan konsentrasi oksigen terlarut yang tinggi di lapisan bawah permukaan (Yuliananingrum \& Putri, 2012).

Rekonstruksi kondisi laut dan juga iklim yang disebabkan oleh perubahan muka laut ini memerlukan umur absolut contoh inti yang digunakan. Sejauh ini, data umur yang terbit dari contoh inti yang diambil di sekitar daerah penelitian adalah contoh inti dari perairan Bengkulu (Mohtadi et al., 2010) namun belum ada yang membahas mengenai umur sedimen dari perairan Palabuhanratu. Tulisan ini memaparkan hasil pemodelan umur dan analisis proksi iklim dari contoh 
inti sedimen dasar laut untuk penentuan siklus Glasial dan Interglasial Terakhir dan rekonstruksi suhu permukaan laut masa lalu. Pemodelan umur (Hughen 2007) merupakan salah satu tahapan terpenting dalam penelitian paleoseanografi dan paleoklimat. Pemodelan umumnya dilakukan terhadap hasil pentarikhan umur (radiocarbon dating), yaitu melalui pengukuran kandungan isotop ${ }^{14} \mathrm{C}$ dalam cangkang karbonat (Hughen, 2007) dari fosil organisme yang dulunya pernah hidup di lokasi penelitian. Selain pada cangkang, pentarikhan umur radiokarbon juga dapat dilakukan terhadap sisa bahan organik seperti kayu atau daun yang terbawa dari darat ke kawasan perairan. Pentarikan umur dengan metode selain radiokarbon juga dapat dilakukan pada endapan abu gunung api (tefra), jika endapan tersebut didapatkan dalam contoh inti sedimen dasar laut.

\section{METODE PENELITIAN}

\section{Lokasi Penelitian}

Pada 2014, dilakukan analisis laboratorium terhadap contoh inti ini dalam kerangka kegiatan Joint Study Benthic Records of Marine Environment, Climate, and Ecosystem in the Eastern Indian Ocean since the Last Deglaciation (BENTHIC) Fase I pada 2014, sebuah kolaborasi dan kerja sama riset antara Puslitbang Sumberdaya Laut dan Pesisir (P3SDLP), Badan Litbang Kelautan dan Perikanan, Kementerian Kelautan dan Perikanan dengan Marine Geology and Geophysics Division of the First Institute of Oceanography (FIO), State Oceanic Administration (SOA), Tiongkok. Mitra kolaborasi BENTHIC juga melibatkan institusi kelautan dalam negeri, yaitu Puslitbang Geologi Kelautan (P3GL), KESDM dan Puslit Geoteknologi LIPI (P2G LIPI).

Contoh inti sedimen SO184-10043 (7¹8,57' LS, $105^{\circ} 3,45^{\prime} \mathrm{BT}$, kedalaman $2.166 \mathrm{~m}$ dan panjang 360 cm) diambil pada 2005 dari dasar laut kawasan lepas pantai Palabuhanratu di ujung selatan Selat Sunda menggunakan Kapal Riset Sonne dalam rangka pelayaran ilmiah PABESIA (Hebbeln et al., 2006; Gambar 1). Contoh inti sedimen tersebut kemudian disimpan di cold storage Laboratorium Contoh Inti milik Puslitbang Geologi Kelautan (P3GL), KESDM di Cirebon, Jawa Barat.

Contoh inti sedimen S0184-10043 telah dipotong menjadi empat bagian dengan panjang $1 \mathrm{~m}$ atau kurang dan kemudian dibelah menjadi dua bagian. Satu bagian digunakan untuk keperluan analisis dan bagian lainnya digunakan sebagai arsip yang disimpan di Laboratorium Contoh Inti P3GL, KESDM di Cirebon. Deskripsi contoh inti sedimen, merujuk pada hasil deskripsi yang telah dilakukan selama cruise berlangsung (Hebbeln et al., 2006).

Penentuan titik kedalaman cuplikan contoh yang digunakan untuk pentarikhan dilakukan dengan melihat hasil pengukuran oksigen isotop $\left(\delta^{18} \mathrm{O}\right)$ dari foraminifera planktonik Globigerinoides ruber. Pencuplikan contoh untuk $\delta^{18} \mathrm{O}$ dilakukan dengan interval $5 \mathrm{~cm}$ sepanjang contoh inti. Preparasi contoh untuk foraminifera meliputi pencucian dan pemisahan contoh dengan pengayakan (sieving) dengan menggunakan ayakan berukuran 230 mesh untuk memisahkan contoh berukuran butir pasir yang mengandung foraminifera dari material berukuran lanau dan lempung. Setelah pengayakan, dilanjutkan dengan pengeringan contoh pada suhu $40^{\circ} \mathrm{C}-60^{\circ} \mathrm{C}$ selama semalam (Montaggioni \& Vénec Peyré, 1993; Vilela \& Maslin, 1997; Ding et al., 2013). Contoh yang sudah kering diayak kembali untuk memisahkan contoh menjadi 3 bagian sesuai ukurannya, yaitu < $250 \mu \mathrm{m}, 250-350 \mu \mathrm{m}$, dan $>350$ $\mu \mathrm{m}$. Penjentikan Globigerinoides ruber untuk isotop $\delta^{18} \mathrm{O}$ dilakukan pada fraksi 250 - $350 \mu \mathrm{m}$ dan penjentikan foraminifera planktonik untuk 14C dilakukan pada fraksi 250 - $350 \mu \mathrm{m}$ dan > $350 \mu \mathrm{m}$.

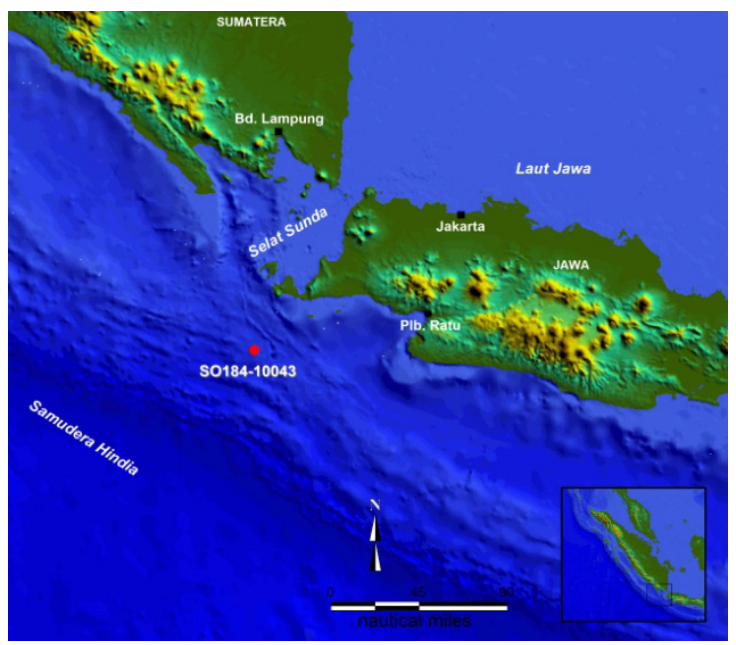

Gambar 1. Lokasi contoh inti sedimen (gravity core sediment sample) S0184-10043. 
Kedua fraksi tersebut dipilih untuk menghindari variasi intra dan antar spesies.

Sebanyak 63 cuplikan contoh digunakan untuk analisis $\delta^{18} \mathrm{O}$. Penjentikan dilakukan untuk mendapat Globigerinoides ruber dengan jumlah individu antara 9 dan 20 dari fraksi $250-350 \mu \mathrm{m}$. Globigerinoides ruber hasil penjentikan dipecahkan kemudian dicuci dengan metanol dan air deionisasi. Pengukuran dilakukan dengan menggunakan Finnigan MAT 252 mass spectrometer dari State Key Laboratory of Marine Geology, Tongji University di Shanghai, Tiongkok. Pentarikhan dilakukan terhadap 16 cuplikan contoh yang diambil antara kedalaman 25 dan $351 \mathrm{~cm}$ dengan jumlah individu berkisar 350 - 1100. Foraminifera planktonik yang digunakan umumnya adalah Globigerinoides ruber sebanyak sekitar $10 \mathrm{mg}$ yang setara dengan sekitar 600 - 1000 individu berukuran > $250 \mu \mathrm{m}$. Jika jumlahnya tidak mencukupi maka contoh ditambah dengan Globigerinoides sacculifer, Globigerinoides trilobus, Globigerinoides immaturus dan Globigerinoides bulloides. Keempat spesies tambahan tersebut dipilih karena memiliki bahan pembentuk dan hidup di kedalaman kolom air yang hampir sama dengan Globigerinoides ruber sehingga memperkecil pengaruh kedalaman terhadap penyerapan ${ }^{14} \mathrm{C}$ oleh foraminifera planktonik tersebut. Pentarikhan umur dilakukan dengan accelerated mass spectrometry (AMS) dan perhitungan umur konvensional mengikuti Stuiver \& Polach (1977). Umur kalender yang diperoleh, disajikan dengan format sebagai berikut: "tahun yang lalu" atau " $y r B P$ " dengan menggunakan 1950 sebagai umur 0 untuk penghitungan umur kalender (Stuiver \& Polach, 1977).

\section{HASIL DAN PEMBAHASAN}

\section{Pemodelan Umur}

Untuk menentukan siklus Glasial dan Interglasial Terakhir dan rekonstruksi suhu permukaan laut masa lalu telah dilakukan pemodelan umur. Hasil Pentarikhan ${ }^{14} \mathrm{C}$ terhadap 16 cuplikan contoh memperlihatkan umur yang semakin tua ke bawah (Gambar 2-A) dengan umur radiokarbon konvensional berkisar $2.100 \pm 25$ tahun yang lalu hingga $27.700 \pm 310$ tahun yang lalu. Umur radiokarbon konvensional cuplikan contoh dari kedalaman $170 \mathrm{~cm}$ memberikan hasil yang lebih muda dari contoh di atasnya $(165 \mathrm{~cm})$ - yang diperkirakan akibat dari aktivitas penggalian (burrowing) oleh organisme yang mengganggu sedimen pada kedalaman ini. Oleh karena itu, umur radiokarbon yang didapatkan dari cuplikan contoh $170 \mathrm{~cm}$ diabaikan dalam pemodelan umur tersebut. Kecepatan sedimentasi rata-rata dari umur ${ }^{14} \mathrm{C}$ konvensional adalah $25 \mathrm{~cm} / 1.000$ tahun (kyr) dengan kecepatan sedimentasi terendah adalah $5 \mathrm{~cm} / \mathrm{kyr}$ dan kecepatan tertinggi $100 \mathrm{~cm} / \mathrm{kyr}$. Umur konvensional menunjukkan hubungan polinomial $y=0,2121 x^{2}-6,5855 x+2783,6$ dengan nilai korelasi yang sangat baik $\left(R^{2}=0,9932\right)$.

Umur ${ }^{14} \mathrm{C}$ konvensional dikalibrasi untuk mendapatkan umur kalender. Kalibrasi dilakukan dengan membandingkan dua perangkat lunak untuk kalibrasi umur ${ }^{14} \mathrm{C}$, yaitu FAIRBANKS (Gambar 2-B) dan CALIB (Gambar 2-C), dengan dua umur reservoir meliputi umur reservoir global (400 tahun) (Stuiver \& Braziunas, 1993; Bradley, 1999) dan umur reservoir dari data terdekat lepas pantai Palabuhanratu sebesar 462 tahun (Southon et al., 2002). Hasil kalibrasi menggunakan FAIRBANKS dengan umur reservoir 462 tahun menghasilkan umur kalender yang berkisar 1.649 tahun yang lalu hingga 32.666 tahun yang lalu (Gambar 2-B). Umur kalender tersebut menunjukkan hubungan polinomial $y=0,2658 x^{2}-$ $11,352 x+2.645,6$ dan $R^{2}=0,9921$. Sedangkan hasil kalibrasi menggunakan CALIB dengan umur reservoir yang sama (462 tahun), memberikan umur kalender berkisar 1.639 tahun yang lalu hingga 31.174 tahun yang lalu. Umur kalender tersebut menunjukkan hubungan polinomial $y=0,2461 x^{2}-5,824 x+2.387$ dan $\mathrm{R}^{2}=0,9951$ (Gambar 2-C). Kecepatan sedimentasi hasil dari kalibrasi FAIRBANKS rata-rata $23 \mathrm{~cm} /$ kyr, kecepatan tertinggi $114 \mathrm{~cm} / \mathrm{kyr}$ dan terendah 4 $\mathrm{cm} / \mathrm{kyr}$ (Gambar 2-D). Kecepatan ini lebih rendah dibandingkan kecepatan sedimentasi yang dihasilkan dari kalibrasi menggunakan CALIB, yaitu rata-rata 25 $\mathrm{cm} / \mathrm{kyr}$ dengan kecepatan tertinggi $132 \mathrm{~cm} / \mathrm{kyr}$ dan terendah $5 \mathrm{~cm} / \mathrm{kyr}$ (Gambar 2-D). Meskipun hanya terdapat sedikit perbedaan hasil kalibrasi pada kedua metode tersebut, dalam penelitian ini digunakan kalibrasi dengan perangkat lunak CALIB karena nilai $\mathrm{R}^{2}$ yang didapatkan lebih tinggi dibandingan dengan menggunakan FAIRBANKS.

Hasil kalibrasi umur kalender tersebut telah menunjukkan bahwa contoh inti sedimen SO18410043 diendapkan dalam rentang waktu antara 32.510 tahun yang lalu hingga saat ini atau sejak Marine Isotope Stage (MIS) 3 hingga Holosen (Lisiecki \& Raymo, 2005). Kecepatan sedimentasi dari MIS 3 hingga Jaman Es Terakhir (Last Glacial Maximum/ LGM) atau 29.000 - 14.000 tahun yang lalu (Lisiecki \& Raymo, 2005) adalah < $10 \mathrm{~cm} / \mathrm{kyr}$ dan semakin meningkat menjadi $15 \mathrm{~cm} / \mathrm{kyr}$ pada $14.000-8.800$ tahun yang lalu. Kecepatan sedimentasi meningkat $400 \%$ antara 8.800 dan 8.000 tahun yang lalu, sebelum kembali lagi ke $15 \mathrm{~cm} / \mathrm{kyr}$ pada 5.429 tahun yang lalu. Terjadi lonjakan besar kecepatan sedimentasi hingga mencapai $132 \mathrm{~cm} / \mathrm{kyr}$ pada 5.078 tahun yang lalu, sebelum turun kembali hingga $15-20 \mathrm{~cm} / \mathrm{kyr}$ dan bertahan hingga saat ini (Gambar 2-D).

Lonjakan besar kecepatan sedimentasi yang teramati pada kedalaman $100 \mathrm{~cm}$ dan $175 \mathrm{~cm}$ tidak diiringi dengan perubahan nilai $\delta^{18} \mathrm{O}$ maupun isotop ${ }^{14} \mathrm{C}$. 

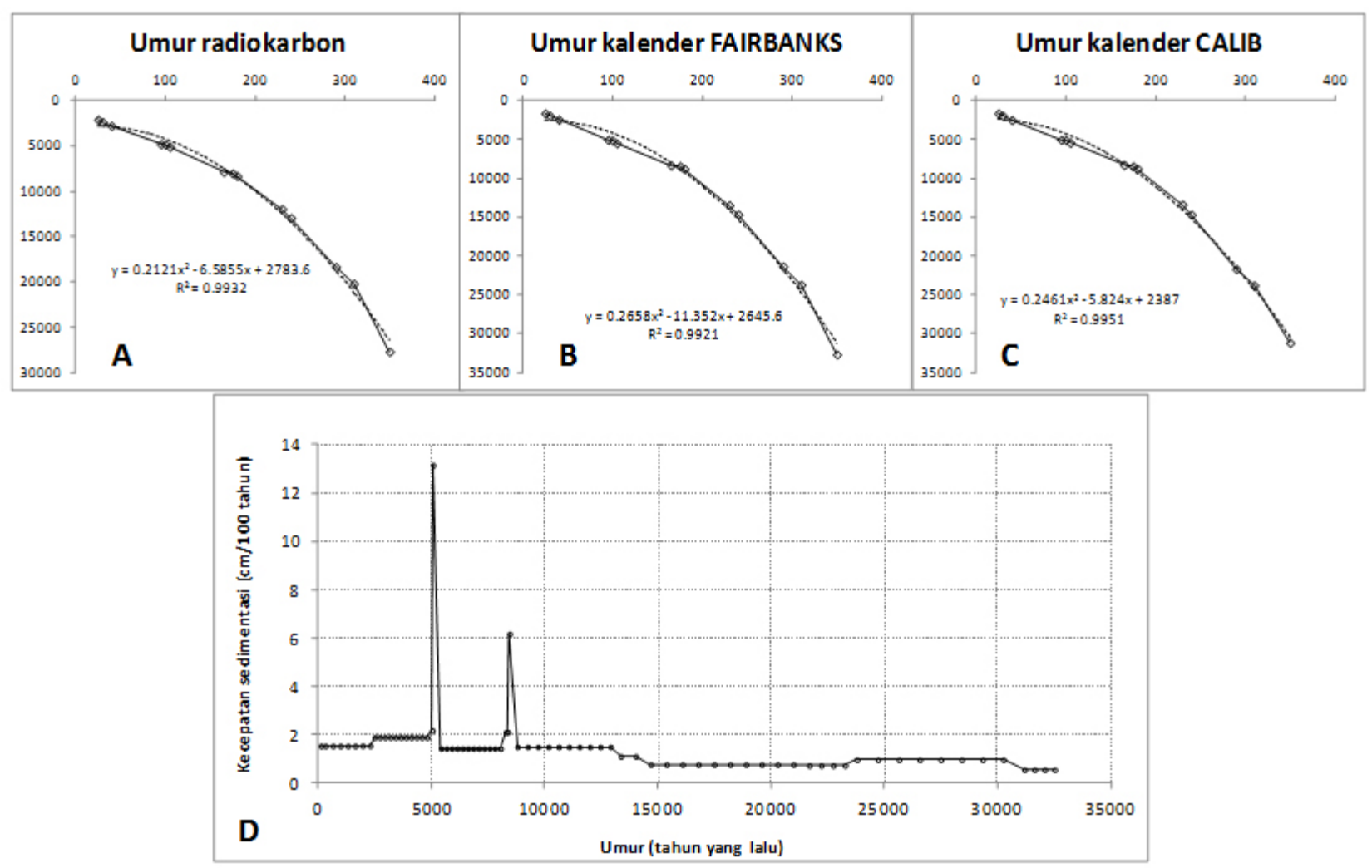

Gambar 2. Pemodelan umur dari data 14C berdasarkan: A) Umur konvensional (belum dikonversi ke umur kalender); B) Umur kalender dengan menggunakan konversi FAIRBANKS; C) Umur kalender dengan menggunakan konversi CALIB; kedua umur kalender dikonversi dengan menggunakan umur reservoir 462 tahun dari data Southon et al. (2002); D) Kecepatan sedimentasi di lokasi penelitian dalam satuan $\mathrm{cm} / 1.000$ tahun $(\mathrm{cm} / \mathrm{kyr})$.

Hal ini menunjukkan bahwa peningkatan kecepatan sedimentasi tidak terkait dengan perubahan iklim. Hasil pengamatan megaskopis terhadap contoh inti (Hebbeln et al., 2006), juga tidak menunjukkan adanya perubahan mekanisme sedimentasi, seperti arus turbidit maupun vulkanisme pada kedalaman tersebut. Peningkatan kecepatan sedimentasi diduga dipengaruhi oleh penggunaan piston core dalam pengambilan contoh inti sedimen, sehingga lonjakan kecepatan sedimentasi yang terjadi kemungkinan besar bukan disebabkan oleh fenomena alam. Hal yang sama pernah teramati pada penelitian di Laut Timor (Holbourn et al., 2005).

Hasil pemodelan menunjukkan bahwa kecepatan sedimentasi rata-rata daerah penelitian pada kurun waktu 35.000 tahun terakhir lebih tinggi dibandingkan dengan kecepatan sedimentasi dari Laut Timor $(19 \mathrm{~cm} /$ kyr; dalam Holbourn et al., 2005) tetapi lebih rendah dari perairan selatan Jawa $(37 \mathrm{~cm} / \mathrm{kyr}$; dalam Mohtadi et al., 2011), namun jauh lebih tinggi daripada lepas pantai Bengkulu (8,5 cm/kyr, Mohtadi et al., 2010). Perbedaan kecepatan sedimentasi antara daerah penelitian dengan contoh inti sedimen dari lepas pantai Bengkulu, diduga disebabkan lokasi contoh S0184-10043 yang terletak di bagian hilir dari alur sungai bawah laut purba yang berhulu di daratan bagian selatan Sumatera yang menerus ke Selat Sunda dengan aliran berarah timur laut barat daya (Voris, 2000) dan diduga mengangkut material sedimen asal daratan dan bermuara ke perairan lepas pantai Palabuhanratu (Gambar 3). Selain berasal dari sungai purba, material sedimen asal darat juga diduga berasal dari sekitar Palabuhanratu yang dipotong oleh Sesar Cimandiri (Hall et al., 2007) sepanjang S. Cimandiri yang mengalir ke baratdaya membawa batuan rombakan sepanjang jalur sesar yang hancur akibat aktivitas Sesar Cimandiri. Sumber sedimen lainnya dapat berasal dari sekitar aliran S. Cisolok sekarang (Banten selatan) atau S. Ciletuh di selatan S.Cimandiri. Material asal darat yang terangkut ke lereng di lepas pantai Palabuhanratu diperkirakan terangkut hingga ke lokasi contoh.

\section{Isotop oksigen}

Hasil pengukuran $\delta^{18} \mathrm{O}$ tertera dalam Gambar 4 


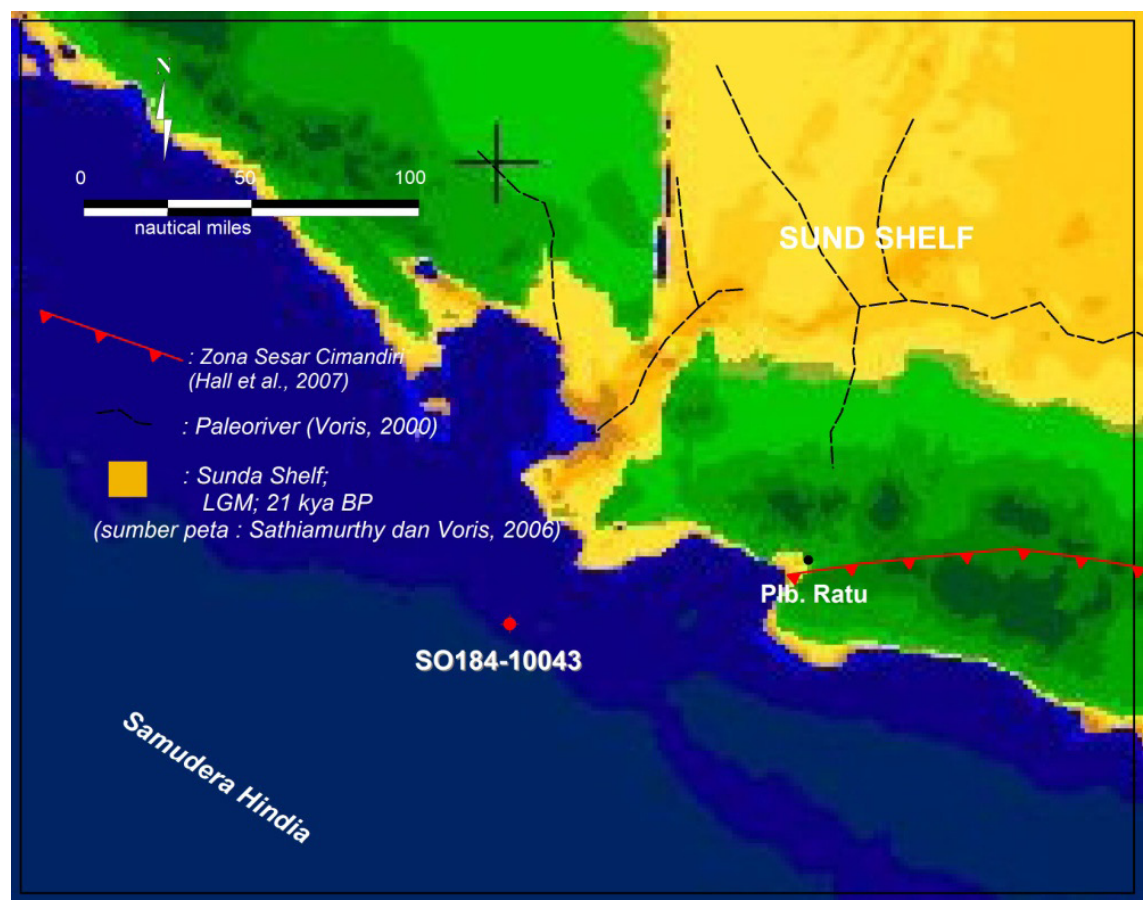

Gambar 3. Contoh inti sedimen S0184-10043 yang terletak di bagian hilir dari alur sungai bawah laut purba (paleochannel) yang berhulu di daratan bagian selatan Sumatera yang menerus ke Selat Sunda dengan aliran berarah timur laut barat daya (Voris, 2000) dan diduga mengangkut material sedimen asal daratan dan bermuara ke perairan lepas pantai Palabuhanratu (sumber peta: Sathiamurthy \& Voris, 2006). Garis merah menunjukkan zona Sesar Cimandiri yang memotong Palabuhanratu (Hall et al., 2007).

yang menunjukkan Siklus Glasial - Interglasial yang terdiri atas Marine Isotope Stage 3 (MIS 3), Periode Jaman Es, Deglasiasi dan Periode Interglasial. Marine Isotope Stage 3 seharusnya merupakan periode Interglasial (hangat), namun karena fluktuasi intensitas sirkulasi termohalin global akibat masuknya air tawar dari lapisan es yang mencair di sekitar Atlantik Utara menyebabkan periode ini menjadi periode yang cukup dingin.

Pengukuran isotop oksigen tersebut telah memberikan nilai rata-rata $\delta^{18} \mathrm{O}$ contoh inti SO18410043 sebesar $-1,86 \%$ dengan nilai terendah $-3,03 \%$ o dan nilai tertinggi $-0,52 \%$. Isotop oksigen bertambah berat dari $-1,86 \%$ o pada 32.510 tahun yang lalu hingga mencapai nilai terberat yaitu $-0,52 \%$ o pada 19.581 tahun yang lalu. Pada saat Deglasiasi (Termination I), terjadi perubahan yang besar pada nilai isotop oksigen, dari $-0,52 \%$ o pada 19.581 tahun yang lalu menjadi $-3,03 \%$ pada 4.578 tahun yang lalu. Isotop oksigen tidak banyak berubah dari 4.578 tahun yang lalu hingga sekarang dan berfluktuasi di sekitar $-2,68 \%$. Nilai isotop oksigen pada saat LGM yang terdeteksi pada G. ruber dari daerah penelitian merupakan nilai isotop oksigen terendah yang dijumpai di sekitar perairan Indonesia. Hasil penelitian terdahulu memberikan nilai isotop oksigen $G$. ruber pada saat LGM di lepas pantai Bengkulu -1,1\%o (Mohtadi et al., 2010), sedangkan di
Laut Timor $\sim 0.9 \%$ (Xu et al., 2008) dan di Laut Banda $>1 \%$ (Spooner et al., 2005).

Gambar 4 Hasil analisis $\delta^{18} \mathrm{O}$ contoh inti sedimen SO184-10043 yang menunjukkan Siklus Glasial - Interglasial. Termination I dikenal juga sebagai Deglasiasi. Tanda panah menunjukkan cuplikan contoh yang digunakan untuk pentarikhan radiokarbon, sedangkan tanda panah merah menunjukkan hasil pentarikhan yang tidak digunakan dalam pemodelan umur; (bawah): Suhu permukaan laut yang didapatkan dari perhitungan menggunakan persamaan Shackleton \& Opdyke (1973).

Perbedaan nilai isotop oksigen saat deglasiasi juga memberikan nilai tertinggi yaitu sebesar $\sim 2,5 \%$ o jika dibandingkan dengan Laut Timor yang bernilai $\sim 2 \%$ o (Xu et al., 2008), lepas pantai Bengkulu yang bernilai 2,2\%o (Mohtadi et al., 2010), dan Laut Banda dengan nilai $\sim 1,6 \%$ (Spooner et al., 2005). Perbedaan isotop oksigen saat deglasiasi tersebut menunjukkan pengaruh perubahan volume es $(1-1,1 \%)$ sehingga jika dikoreksi terhadap volume es, perbedaan nilai isotop oksigen daerah penelitian saat deglasiasi adalah $1,4-1,5 \%$. Perbedaan isotop oksigen deglasiasi yang sudah dikoreksi terhadap volume es ini nilainya masih jauh lebih besar dari yang diamati oleh Spooner et al. (2005) di Laut Banda yaitu bernilai 

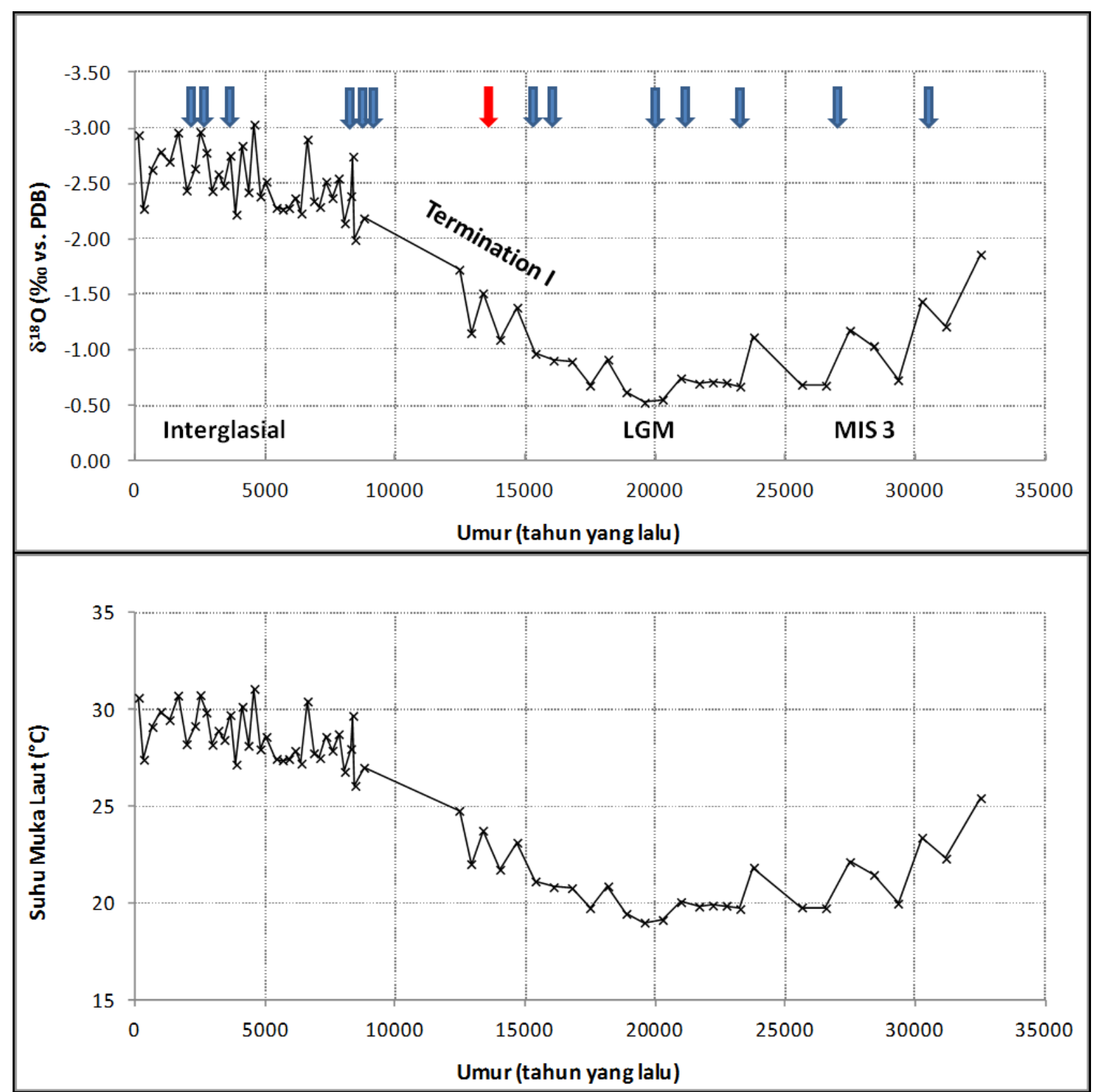

Gambar 4. Hasil analisis $\delta^{18} \mathrm{O}$ contoh inti sedimen SO184-10043 yang menunjukkan Siklus Glasial Interglasial. Termination I dikenal juga sebagai Deglasiasi. Tanda panah menunjukkan cuplikan contoh yang digunakan untuk pentarikhan radiokarbon, sedangkan tanda panah merah menunjukkan hasil pentarikhan yang tidak digunakan dalam pemodelan umur; (bawah): Suhu permukaan laut yang didapatkan dari perhitungan menggunakan persamaan Shackleton \& Opdyke (1973).

$0,4 \%$. Perbedaan tersebut diduga dipengaruhi oleh kenaikan salinitas permukaan laut meskipun data dari lepas pantai Bengkulu tidak menunjukkan adanya perubahan salinitas saat deglasiasi yang berkaitan dengan fluktuasi curah hujan (Mohtadi et al., 2010). Selain fluktuasi curah hujan, proses terhubungnya Laut Jawa dengan Samudera Hindia saat deglasiasi (Voris, 2000) diduga juga memberikan pengaruh terhadap nilai isotop oksigen di daerah penelitian sebesar $\sim 0,3 \%$ jika dibandingkan dengan contoh inti sedimen dari lepas pantai Bengkulu yang tidak dipengaruhi oleh terhubungnya Laut Jawa tersebut.

\section{Suhu Permukaan Laut}

Perhitungan suhu permukaan laut umumnya didapatkan melalui pengukuran $\mathrm{Mg} / \mathrm{Ca}$ dari cangkang G. ruber untuk melengkapi data oksigen isotop yang sudah ada. Pada penelitian ini, jumlah contoh untuk pengukuran kurang memadai sehingga tidak 
dapat dilakukan pengukuran $\mathrm{Mg} / \mathrm{Ca}$ dari cangkang Globigerinoides ruber. Meskipun demikian, perhitungan suhu permukaan laut masa lampau masih dapat dilakukan dengan menggunakan beberapa asumsi sebagai berikut: 1) Perbedaan oksigen isotop air laut $\left(\delta^{18} \mathrm{O}_{\mathrm{sw}}\right)$ Glasial - Interglasial adalah $0,4 \%$ o (Emiliani, 1955 dalam Shackleton \& Opdyke, 1973) dan nilai $\delta^{18} \mathrm{O}_{\mathrm{sw}}$ tidak banyak berubah sejak Holosen Akhir hingga saat ini. Dengan menggunakan kedua asumsi tersebut, maka suhu permukaan laut antara 0 dan 35.000 tahun yang lalu dapat dihitung dengan persamaan: $\mathrm{T}=16,9$ $-4,3^{*}\left(\delta^{18} \mathrm{O}\right)+0,4^{*}\left(\delta^{18} \mathrm{O}\right)^{2}$ (Shackleton \& Opdyke, 1973), sehingga didapatkan hasil seperti yang diperlihatkan pada Gambar 4 bagian bawah.

Suhu permukaan laut daerah penelitian pada saat MIS 3 sekitar $25^{\circ} \mathrm{C}$ dan perlahan turun hingga mencapai suhu terendah $19^{\circ} \mathrm{C}$ pada saat LGM ( 19.581 tahun yang lalu). Suhu pada saat LGM berfluktuasi di sekitar $20^{\circ} \mathrm{C}$, sebelum naik perlahan pada saat deglasiasi hingga mencapai suhu tertinggi $31^{\circ} \mathrm{C}$ pada 4.578 tahun yang lalu. Selama akhir Holosen, suhu permukaan laut berfluktuasi di sekitar $29^{\circ} \mathrm{C}$ yang merupakan suhu rata-rata muka laut di perairan Indonesia (Schlitzer, 2013). Hasil rekonstruksi suhu permukaan laut selama 35.000 tahun terakhir di Laut Timor memberikan nilai $24^{\circ} \mathrm{C}$ pada saat LGM dan $\sim 29^{\circ} \mathrm{C}$ pada saat Holosen Akhir (Xu et al., 2008). Di lepas pantai Bengkulu, suhu permukaan laut pada saat LGM berkisar di $24^{\circ} \mathrm{C}$ dan pada saat Holosen Akhir berkisar $26^{\circ} \mathrm{C}$ (Mohtadi et al., 2010). Di Laut Banda $\sim 3^{\circ} \mathrm{C}$ lebih dingin dari kondisi saat ini (Spooner et al., 2005). Perbedaan nilai hasil rekonstruksi suhu dalam penelitian sebelumnya, dapat disebabkan oleh perbedaan metode rekonstruksi suhu yang digunakan dan proses lokal yang terjadi di daerah penelitian. Pada penelitian ini, rekonstruksi suhu dilakukan dengan data $\delta^{18} \mathrm{O}$, sedangkan rekonstruksi suhu penelitian terdahulu dari Laut Timor dan lepas pantai Bengkulu, didasarkan dari hasil pengukuran $\mathrm{Mg} / \mathrm{Ca}$ dan pengukuran suhu di Laut Banda sendiri, digunakan metoda transfer function.

Perbedaan suhu deglasiasi di daerah penelitian sekitar $\sim 9^{\circ} \mathrm{C}$ yang nilainya dua hingga tiga kali lebih besar dari perbedaan suhu yang diamati oleh ketiga peneliti terdahulu tersebut diduga menunjukkan pengaruh curah hujan terhadap salinitas permukaan laut daerah penelitian seperti yang terlihat pada data $\delta^{18} \mathrm{O}$. Ketika Paparan Sunda tersingkap saat LGM, aliran air dari Laut Cina Selatan dengan salinitas yang lebih rendah dan melalui Selat Karimata terhenti dan terjadi lagi sekitar 9,500 tahun yang lalu (Xu et al., 2008) saat muka laut mencapai kedalaman $30-40$ meter di bawah permukaan laut sekarang (Lambeck \& Chappell, 2001). Selain itu, data $\delta^{18} \mathrm{O}$ dari daerah penelitian menunjukkan masih harus dikoreksi terhadap efek salinitas. Dalam hal ini, koreksi tidak dapat dilakukan karena pengukuran $\mathrm{Mg} / \mathrm{Ca}$ untuk mengetahui suhu air laut di daerah penelitian juga tidak dilakukan. Oleh sebab itu, rekonstruksi suhu di daerah penelitian tidak dapat dilakukan hanya dengan mengandalkan data $\delta^{18} \mathrm{O}$ tetapi mesti dilengkapi dengan data $\mathrm{Mg} / \mathrm{Ca}$.

\section{KESIMPULAN}

Hasil pentarikhan umur isotop karbon-14 $\left({ }^{14} \mathrm{C}\right)$ dari lokasi penelitian di lepas pantai Palabuhanratu menunjukkan bahwa sedimen telah terendapkan sejak 35.000 tahun yang lalu. Tidak ada perbedaan berarti yang didapatkan dari hasil konversi umur konvensional menjadi umur kalender, baik dengan menggunakan metoda FAIRBANKS ataupun CALIB selama konversi tersebut dilakukan dengan menggunakan umur reservoir yang sama. Lonjakan kecepatan sedimentasi pada contoh yang dianalisis dengan tidak diiringi oleh perubahan mekanisme pengendapannya menunjukkan bahwa lonjakan ini lebih disebabkan pengaruh metode pengambilan contoh yang menggunakan piston corer.

Hasil pengukuran $\delta^{18} \mathrm{O}$ yang digunakan untuk melakukan rekonstruksi suhu permukaan laut menggunakan persamaan Shackleton \& Opdyke (1973) menunjukkan adanya Siklus Glasial - Interglasial pada contoh inti SO184-10043. Periode Interglasial yang dikenali adalah Interglasial terakhir dan MIS 3 (Marine Isotope Stage 3). MIS 3 seharusnya merupakan periode Interglasial namun mengalami perubahan iklim akibat fluktuasi intensitas sirkulasi termohalin global sehingga periode ini menjadi periode yang cukup dingin. Periode ini diikuti oleh Periode Jaman Es Terakhir dengan kondisi terdingin yang dikenal dengan Last Glacial Maximum (LGM) terjadi pada 19.581 tahun yang lalu. Setelah LGM, terjadi kenaikan suhu permukaan laut secara perlahan yang dikenal dengan periode Deglasiasi ( 17.400 hingga 8.000 tahun yang lalu) yang kemudian diikuti oleh Periode Interglasial Terakhir yang terjadi sejak sekitar $~ 8.000$ tahun yang lalu hingga saat ini.

Rekonstruksi suhu permukaan laut dari data $\delta^{18} \mathrm{O}$ telah menunjukkan suhu deglasiasi jauh lebih tinggi dari daerah lainnya yang diduga karena faktor lokal yang mempengaruhi salinitas. Karena itu, rekonstruksi suhu permukaan laut daerah penelitian tidak dapat dilakukan hanya dengan menggunakan data isotop oksigen, tetapi memerlukan data lainnya seperti data $\mathrm{Mg} / \mathrm{Ca}$ ataupun kumpulan foraminifera. Meskipun tidak bisa dipakai langsung untuk rekonstruksi suhu permukaan laut masa lalu secara kuantitatif, tetapi pola perubahan suhu yang dicerminkan oleh data $\delta^{18} \mathrm{O}$ tersebut secara kualitatif masih dapat dijadikan acuan.

\section{PERSANTUNAN}

Ucapan terima kasih disampaikan kepada Dr. Budi Sulistiyo selaku Kepala Puslitbang Sumberdaya Laut 
dan Pesisir, Badan Litbang Kelautan dan PerikananKKP; Dr. Susilohadi selaku Kepala Puslitbang Geologi Kelautan, Badan Litbang ESDM-KESDM; dan Dr. Haryadi Permana selaku Kepala Puslit GeoteknologiLIPI; serta Prof. Xuefa Shi selaku Direktur Marine Geology and Geophysics Division of the First Institute of Oceanography (FIO); yang telah mendukung terlaksananya kegiatan kolaborasi dan kerja sama riset kelautan ini. Sebagian besar data yang digunakan dalam tulisan ini telah dibiayai oleh dana hibah proyek kerja sama riset BENTHIC antara Badan Litbang Kelautan dan Perikanan, Kementerian Kelautan dan Perikanan, Indonesia dengan The First Institute of Oceanography, State Oceanic Administration, Tiongkok. Contoh inti sedimen dan deskripsinya yang diacu sebagai data awal adalah hasil pelayaran ilmiah PABESIA tahun 2005 yang merupakan kerja sama riset kelautan antara Indonesia - Jerman.

Kepada seluruh rekan teknisi laboratorium dari berbagai institusi yang terlibat langsung dalam penelitian ini (P3SDLP, P3GL, P2G LIPI, FIO, Tongji University) dan telah membantu mempersiapkan preparasi contoh hingga pengukuran geokimia dan pentarikhan umur, diucapkan terimakasih atas peran sertanya tersebut.

\section{DAFTAR PUSTAKA}

Bradley, R. S. (1999). Paleoclimatology. Reconstructing climates of the Quaternary. Second edition. Dalam R. Dmowska, \& J. R. Holton (Editor), International Geophysics series, Vol. 64. Harcourt/Academic Press. 200 Wheeler Road, Burlington, MA 01803.

Ding, X., Bassinot, F., Guichard, F., \& Fang, N. Q., (2013). Indonesian Throughflow and monsoon activity records in the Timor Sea since the last glacial maximum, Marine Micropaleontology, Vol 101, 115-126.

Hall, Robert., B. Clements, H.R. Smyh. \& Cottam, M. A. (2007). A New Interpretation of Java Structure. Proceedings 31st Annual Convention and Exhibition of Indonesia Petroleum Association, IPA07-G-035.

Hebbeln, D., T. Jennerjahn, M. Mohtadi, H. Andruleit, A. Baumgart, M. Birkicht, C. Chiessi, A. Damar, B. Donner, N. Fadly, M. Gröning, W.S. Hantoro, C. Hayn, U.R. Kadarwati, K. Kamija, T.L. Kepel, N. Krück, F. Lamy, J. Langer, H.A. Mai, T. Mehring, B. Meyer-Schack, G. Mollenhauer, O. Morisse, A. Müller, A.K. Permana, W.S. Pranowo, D.A.S. Ranawijaya, O. Romero, G. Ruhland, J. Scholten, J. Smit, C. Spliethoff, S. Steinke, R. Thomas, C. Wienberg \& Yurnaldi, D. (2006). Report and Preliminary Results of RV Sonne
Cruise SO-184, PABESIA, Durban (South Africa)

- Cilacap (Indonesia) - Darwin (Australia), July 8 - September 13, 2005. Berichte, Fachbereiche Geowissenschaften, Universität Bremen, No. 246. Bremen, $142 \mathrm{p}$.

Holbourn, A., Kuhnt, W., Kawamura, H., Jian, Z., Grootes, P., Erlenkeuser, H. \& Xu, J. (2005). Orbitally paced paleoproductivity variations ion the Timor Sea and Indonesian Throughflow variability during the last $460 \mathrm{kyr}$. Paleoceanography, vol. 20, PA3002, doi: 10.1029/2004PA001094.

Hughen, K.A. (2007). Radiocarbon Dating of DeepSea Sediments. Dalam C. Hillaire-Marcel dan A. De Vernal (Editor), Proxies in Late Cenozoic Paleoceanography, Development in Marine Geology Vol 1., 201-210. Elsevier. Amsterdam.

Lambeck, K. \& Chappell, J. (2001). Sea level change through the last glacial cycle. Science, 292, 679 686, doi:10.1126/science.1059549.

Lisiecki, L.E. \& Raymo, M.E. (2005). A PliocenePleistocene stack of 57 globally distributed benthic $\delta 180$ records. Paleoceanography,. 20, PA1003, doi:10.1029/2004PA001071.

Mohtadi, M., Oppo, D.W., Steinke. S., Stuut, J-B.W., De Pol-Holz, R., Hebbeln, D. \& Lückge, A. (2011). Glacial to Holocene swings of the AustralianIndonesian monsoon. Nature Geoscience, 4, 540-544, DOI: 10.1038/NGEO1209.

Mohtadi, M., Steinke, S., Lückge, A., Groeneveld, J. \& Hathorne, E.C. (2010). Glacial to Holocene surface hydrography of the tropical eastern Indian Ocean. Earth Planet. Sci. Lett., 292, 8997, doi:10.1016/j.epsl.2010.01.024.

Montaggioni, L., F. \& Vénec-Peyré, M. T. (1993). Shallow-water foraminiferal taphocoenoses at site 821: Implications for the pleistocene evolution of the central Great barrier reef shelf, northeastern Australia. Proceedings of the Ocean Drilling Program, Scientific Results, Vol. 133, 365 - 378.

Sathiamurthy, E. \& Voris, H.K. (2006). Maps of Holocene Sea Level Transgression and Submerged Lakes on the Sunda Shelf. The Natural History Journal of Chulalongkorn University, Supplement 2, 1-44.

Schlitzer, R. (2013). Ocean Data View, http://odv.awi. de. Diakses pada tanggal 2 Februari 2014.

Shackleton. N.J. \& Opdyke, N.D. (1973). Oxygen Isotope and Palaeomagnetic Stratigraphy of Equatorial Pacific Core V28-238: Oxygen Isotope 
Temperatures and Ice Volumes on a 105 Year and 106 Year Scale. Quarter. Res., 3, 39-55.

Southon, J., M. Kashgarian, M. Fontugne, B. Metivier, \& Yim, W.W.-S. (2002). Marine reservoir corrections for the Indian Ocean and Southeast Asia. Radiocarbon 44, 167-180.

Spooner, M. I., T. T. Barrows, P. De Deckker \& Paterne, M. (2005). Palaeoceanography of the Banda Sea, and late Pleistocene initiation of the northwest monsoon. Global Planet. Change, 49, 28-46, doi:10.1016/j.gloplacha.2005.05.002.

Stuiver, M. \& Polach, H. A. (1977). Discussion: Reporting of 14C data. Radiocarbon, 19, 355-363.

Stuiver, M. \& Braziunas, T., F. (1993). 14C ages of marine samples to 10,000 BC. Radiocarbon, 35 (1), 137-189.

Vilela, C. G. \& Maslin, M. (1997). Benthic and planktonic foraminifers, and stable isotopic analysis Of massflow sediments in the amazon fan. Proceedings of the Ocean Drilling Program, Scientific Results, Vol. 155, $335-351$.

Voris, K. (2000). Maps of Pleistocene sea levels in Southeast Asia: shorelines, river systems and time durations. Journal of Biogeography, 27, 1153-1167.

Xu, J., W. Kuhnt, A. Holbourn, M. Regenberg \& Andersen, N. (2010). Indo-Pacific Warm Pool variability during the Holocene and Last Glacial Maximum. Paleoceanography, 25, PA4230, doi:10.1029/2010PA001934.

Xu, J., A. Holbourn, W. Kuhnt, Z. Jian \& Kawamura, $H$. (2008). Changes in the thermocline structure of the Indonesian outflow during terminations I and II. Earth Planet. Sci. Lett., 273, 152 - 162, doi:10.1016/j.epsl.2008.06.029.

Yuliananingrum, T. L. P. \& Putri, M. R. (2012). Kondisi Oseanografi di Selat Sunda dan selatan Jawa Barat pada Monsun Barat 2012. Prosiding: Seminar Nasional Kelautan POSEIDON ITB 2012, Institut Teknologi Bandung, v. 1. 